Review

\title{
Process Intensification for Production and Recovery of Biological Products
}

\author{
${ }^{1}$ Hamideh Vaghari, ${ }^{1}$ Maryam Eskandari, ${ }^{1}$ Vahideh Sobhani, \\ ${ }^{2}$ Aydin Berenjian, ${ }^{3}$ Yuanda Song and ${ }^{1}$ Hoda Jafarizadeh-Malmiri \\ ${ }^{I}$ Department of Chemical Engineering, Sahand University of Technology, Tabriz, Iran \\ ${ }^{2}$ School of Engineering, Faculty of Science and Engineering, The University of Waikato, Hamilton, New Zealand \\ ${ }^{3}$ Colin Ratledge Center for Microbial Lipids, School of Agriculture Engineering and Food Science, \\ Shandong University of Technology, Zibo, Shandong, China
}

Article history

Received: 14-01-2015

Revised: 23-01-2015

Accepted: 24-01-2015

Corresponding author:

Aydin Berenjian

School of Engineering, Faculty of

Science and Engineering, The

University of Waikato, Hamilton,

New Zealand

Email: aydin.berenjian@waikato.ac.nz

\begin{abstract}
Bioprocesses are important biological reactions which need several sophisticated methods and equipment to produce many novel and important compounds which some of them are traditionally produced by synthetic chemical reactions. In bioprocesses, the products are often produced in a dilute environment and finally they require a high purity. Because of that, downstream processes are usually included a large number of separation steps. Size and capital costs of the equipment are two main limitations of using bioprocesses at industrial scale. Bioprocess intensification by minimizing, substitution, moderation and simplification of the methods and equipment, drastically leads to sustainable processes. This study looks at intensification of the emerging equipment and operational methods and their advantages to lead smaller and cleaner bioprocess plants which in turn, increases production efficiency and quality and decreases byproducts formation, capital cost and energy consumption.
\end{abstract}

Keywords: Bioprocessing, Intensification, Energy, Equipment Size, Production Capacity

\section{Introduction}

The need for sustainable, efficient and cost effective processes are in demand for many chemical and biological industries (Wohlgemuth, 2009). Several alternatives have been developed to address some of the problems associated with the use of the conventional apparatuses and techniques. Process Intensification (PI) has been known as a method to comply with such requirements (Lutze et al., 2010). Process intensification as a method for making significant changes in the size of a process plants to achieve a given production objective. These reductions can come from decreasing the size of individual equipment or from removing the number of involved unit operations (Stankiewicz and Moulijn, 2000). PI may be defined in a number of ways. One of several definitions of PI sets out a selection of all themes is that "Any chemical engineering development that leads to a substantially smaller, cleaner, safer and more energy efficient technology is process intensification" (Reay et al., 2013). PI refers to replace complex technologies with integrated equipment and processes that are smaller in size, less costly and more efficient (Charpentier, 2007). Preferably, it integrates as many unit operations as possible into a multifunctional ones to be used in the chemical and biological industries (Marques and Fernandes, 2011). Environmentally, however, the most telling impact of PI is likely to be in the development of reactor designs for truly green technology. It is well understood that the reactor is the heart of any chemical process, as it dictates both the product quality and the extent of the downstream separation and treatment equipment. Designing reactors which operate intensively and which give high conversion and selectivity with minimal by-product formation will permit us to approach the green ideal of delivering a high quality product without an extensive downstream purification sequence. Among the 
processes, biological processes need more sustainable production methods and technologies (Clark et al., 2009; Wohlgemuth, 2009). In this article, we take a closer look at bioprocess intensification. We define what it involves and review recent developments in bioprocess-intensifying devices and methods.

\section{Bioprocess Intensification}

A growing tendency towards the use of sustainable resources and production technologies has attracted attention (Van Hecke et al., 2014). Intensive bioprocessing, therefore, has been the subject of many contributions at PI conferences since 1995 (Reay et al., 2013). Bioprocess Intensification (BI) aims to accelerate the overall processing time and/or reduce reactor volume (Akay et al., 2005). A wide range of intensification methods can be used in bioprocessing. Membrane reactors, jet loop and biocatalyst membranes are available for intensify biochemical processes (Akay, 2005). Supported biocatalysts strategies are often used to further improve the catalytic activity and strength of enzymes and microorganisms (Akay et al., 2005). The whole field can be divided into two main areas: (i) Equipment intensification, such as use of novel reactors, heat exchangers and mass transfer units; and (ii) process intensification, such as use of new separation strategies, integration of reaction and separation, phase transition, techniques using alternative energy sources and new control methods. Distinctive features of the process-intensifying methods are summarized in the following subsections.

\section{Equipment}

PI significantly enhances transport rates and it gives every molecule the same processing experience. This definition can be usefully interpreted as being a process development involving dramatically smaller equipment which leads to: Improved control of reactor kinetics giving higher selectivity, reduced waste products, higher energy efficiency, reduced capital costs and reduced inventory, improved intrinsic safety and fast response times. Low and uniform shear is one of the important parameters that should be considered in bioprocesses especially when handling shear-sensitive materials, such as certain pharmaceutical crystals and in flocculators ( $\mathrm{Ni}$ et al., 2001). Intensifying equipment in bioprocesses used to enhance heat transfer and gas-liquid mass transfer which is often the limiting factor in aerobic systems (Reay et al., 2013).

Mixers are fine examples of process-intensifying equipment. The technology of stirring liquid-liquid and gas-liquid systems has been greatly intensified during the past years. Microreactors which usually have a sandwich-like structure consisting of a number of layers with micromachined channels $(10-100 \mu \mathrm{m}$ in dia) can be used for multiple functions such as mixing, heat exchange and catalytic reaction. Integration of these various functions within a single unit is one of the most important advantages of microreactors. These reactors due to their unique specifications allow for operating highly exothermic processes isothermally (Stankiewicz and Moulijn, 2000). Intensification equipment used in bioprocessing is shown in Table 1.

Equipment for operations not involving chemical reactions

Static mixers

Compact heat exchangers

Microchannel heat exchangers

Rotor/stator mixers

Rotating packed beds

Centrifugal adsorber

Supersonic gas/liquid reactor

Jet-impingement reactor

Rotating packed-bed reactor

Table 2. Intensification methods used in bioprocessing

\begin{tabular}{llll}
\hline Multifunctional reactors & Hybrid separations & Alternative energy sources & Other methods \\
\hline Reverse-flow reactors & Membrane absorption & Centrifugal Fields & Supercritical fluids \\
Reactive distillation & Membrane distillation & Ultrasound & Dynamic (Periodic) \\
Reactive extraction & Adsorptive distillation & Solar energy & Reactor operation \\
Reactive crystallization & & Microwaves & \\
Chromatographic reactors & & Electric fields & \\
Periodic separating reactors & & Plasma technology & \\
Membrane reactors & & & \\
Reactive extrusion & & & \\
Reactive comminution & & & \\
Fuel cells & & & \\
\hline
\end{tabular}




\section{Methods}

A wide range of intensification techniques can be used in bioprocessing ranging from high gravity fields, electric fields and ultrasound, to membrane processes and some reactors. Most processintensifying methods as shown in Table 2 are categorized into multifunctional reactors, hybrid separations and alternative energies for processing.

\section{Application of PI in Biological Processes}

Today, a huge research effort is devoted to BI methods. BI methods cause many advantages. Membrane bioreactors, for instance, can be used for selective in-situ separation of the reaction products and to enhance selectivity or yield of a process or to improve mass transfer (Stankiewicz and Moulijn, 2000). Using immobilized cells bioreactors have advantages as compared to free cells bioreactors. Immobilized cell systems allows the use of independent growth rate bioreactors. In addition, catalytic stability are usually greater for immobilized cells than free cells. Some immobilized microorganisms tolerate higher toxicity levels as compared to free cells (Akay et al., 2005). Table 3 shows an overview of the various intensification processes that are or can be used in bioprocesses and their intensifying effect on the processes.

\section{The Advantages of PI}

While size and capital cost reduction were the original target for PI, it quickly became apparent that there were other benefits, some of which have become even more important since PI was conceived. BI results to a significantly smaller size, greener, safer and more efficient technology. Furthermore, PI significantly reduces the time to market, which is the key issue in some sectors such as fine chemicals and biological industries.

Since the essential idea of PI is a large increase in production per unit plant volume, it also results in significant reduction in residence times (typically from hours to seconds for some operations). This has profound implications for the plant's ability to respond quickly to desired process changes in general and for the control philosophy in particular. In any event, it will become possible to switch product grades rapidly with little intermediate off-specification product being generated. Some of distinctive benefits are summarized in the following subsections.

\section{Safety}

Approaches to the design of inherently safer plant could be grouped into four major strategies: Minimizing, substitution, moderation and simplification. Given the anticipated reductions in plant volume through PI methods, the toxic and flammable inventories are correspondingly reduced, thereby making a major contribution to intrinsic plant safety. PI can also allow one to moderate conditions to minimize risk of explosions and to simplify processes by having fewer unit operations and less complex plant (Hendershot, 2003).

\section{The Environment}

There are recommendations by the UK Royal Commission on Environmental Pollution that we need to reduce $\mathrm{CO}_{2}$ emissions by more than $50 \%$ in order to stabilize their impact on global warming (DECC, 2012). $\mathrm{CO}_{2}$ gas is believed to be the principal gas contributing to this phenomenon. So, one of the most interesting and challenging areas of technology is Carbon Capture (CC), normally combined with storage in most literature (Wang et al., 2011). Most current CC plants use old chemical engineering technologies such as static absorption/desorption towers for the most common form of carbon capture, post-combustion capture using absorption of the $\mathrm{CO}_{2}$. CC could become one of the most important applications of PI within the next two decades. The application of PI here is directed at reducing the sizes of the absorption and desorption columns, for example, by carrying out the processes in rotating packed beds and by using compact heat exchangers in other parts of the plant. Other methods involve membranes and intensified adsorption reactions. The rotating packed bed has been examined in Europe and in China in this respect (Cheng and Tan, 2009; Yi et al., 2009). Interestingly, a survey on attitudes to PI revealed that a change to a non-carbon based economy would be a major stimulus for PI (Nikoleris et al., 2002; Reay et al., 2013). These observations lead us neatly into the discussion of the ways in which PI can benefit energy use, which, of course, impacts on the environment in a number of ways, in particular, in carbon emission mitigation.

\section{Energy}

The effectiveness of any PI strategy is ultimately dependent upon success in identifying techniques for dramatically increasing the intensity of the fluid dynamic environment, so as to accelerate the transfer of heat, mass and momentum within a process or operation. The energy savings are largely due to better selectivity and reduced energy use in separation processes, as well as improved control. The UK carried out an assessment of the potential for PI energy savings some years ago. The UK Energy Efficiency Office supported the development of strategies in three areas (i) compact heat exchangers; (ii) heat and mass transfer enhancement; and (iii) process intensification related to saving energy. Compact heat exchangers and in some cases combination of heat exchangers with other alternative energy sources such as microwaves show energy efficiency benefits. Micro- 
fluidic processes (reactions which occur at a micro scale) help to improve energy efficiency, mixing and product yield. There are many practical challenges to overcome in applying these processes to industrial applications, particularly in scaling-up from small volume to bulk manufacture. As part of these strategies, studies were carried out by Linnhoff March, of the energy savings made and data are given in Table 4.

Table 3. Overview of the various applications of intensifying processes which can be used in bioprocesses

\begin{tabular}{|c|c|c|c|}
\hline Equipment & Typical applications & Results of the study & References \\
\hline Higee Bioreactor (HBR) & $\begin{array}{l}\text { Polyhydroxyalkanoate (PHA) production } \\
\text { through fermentation }\end{array}$ & $\begin{array}{l}\text { Higher mass transfer capability, improved } \\
\text { biomass concentration and PHA yield }\end{array}$ & $\begin{array}{l}\text { (Boodhoo et al., 2010) } \\
\text { (Feng et al., 2013) }\end{array}$ \\
\hline $\begin{array}{l}\text { Spinning Cloth Disc Reactor } \\
\text { (SCDR) }\end{array}$ & Enzymes immobilization & $\begin{array}{l}\text { Higher mass transfer rates and } \\
\text { rapid mixing }\end{array}$ & \\
\hline Static mixer & Multiphase reactions & Higher mass transfer & (Al Taweel et al., 2013) \\
\hline Micro-reactors & Drug and fine chemical manufacture & Improved diffusion & (Reay et al., 2013) \\
\hline Monolithic reactors & $\begin{array}{l}\text { 1. Enzymatic oxidation of glucose } \\
\text { 2. Gluconic acid formation by } \\
\text { gloconobacter suboxydanse } \\
\text { 3. Hydrogen production by Clostridium butyricum }\end{array}$ & & (Dunford, 2012) \\
\hline Heat exchange reactors & $\begin{array}{l}\text { Fast exothermic reactions nitration, azo } \\
\text { coupling, halogenation, hydrogenation } \\
\text { oxidation, sulfonation amination and alkylation }\end{array}$ & $\begin{array}{l}\text { Safer processing, } \\
\text { Better economics and } \\
\text { More energy-efficient }\end{array}$ & $\begin{array}{l}\text { (Anxionnaz et al., } \\
2008 \text { ) }\end{array}$ \\
\hline Microchannel reactor & $\begin{array}{l}\text { Synthesis of metallo-organics, } \\
\text { Radical acrylate polymerization, } \\
\text { Liquid-phase reactions (catalytic or non-catalytic), } \\
\text { Gas-liquid reactions (halogenations, nitrations) and } \\
\text { Gas-phase reactions (oxidations, hydrogenations) }\end{array}$ & $\begin{array}{l}\text { Easily and efficiently heat transfer, } \\
\text { Improved control of transfer processes } \\
\text { and heat management, } \\
\text { Increase the process selectivity and product purity }\end{array}$ & $\begin{array}{l}\text { (Anxionnaz et al., } \\
2008 \text { ) }\end{array}$ \\
\hline Electrically enhanced reactions & $\begin{array}{l}\text { Bioreactions, break up droplets into micron sizes, } \\
\text { Hydrolytic splitting of esters to yield free fatty } \\
\text { acids and glycerol }\end{array}$ & Enhancement of heat and mass transfer & (Reay et al., 2013) \\
\hline Continuous stirred tank reactor & $\begin{array}{l}\text { Crystallisation, bioreactions, hazardous reactions, } \\
\text { general pharmaceutical and fine chemical reactions }\end{array}$ & $\begin{array}{l}\text { Overcomes batch limitations, cheap, can } \\
\text { be used in series, easy to clean, better } \\
\text { temperature control than batch STR }\end{array}$ & (Reay et al., 2013) \\
\hline Structured packing & reactions involving slurry catalysts & $\begin{array}{l}\text { Better mixing and } \\
\text { radial heat-transfer }\end{array}$ & (Stringaro et al., 1998) \\
\hline $\begin{array}{l}\text { Oscillatory flow screening } \\
\text { meso-reactor }\end{array}$ & $\begin{array}{l}\text { Production of an aroma compound } \\
\gamma \text {-decalactone using } Y . \text { lipolytica cells }\end{array}$ & $\begin{array}{l}50 \% \text { reduction in time to required } \\
\text { conversion, enhance liquid-liquid mixing }\end{array}$ & (Reis et al., 2006) \\
\hline $\begin{array}{l}\text { Fixed-bed bioreactor using micro- } \\
\text { cellular polymer-immobilized cells }\end{array}$ & $\begin{array}{l}\text { production of } \alpha \text {-amylase by immobilized } \\
\text { Bacillus subtilis in porous polymeric polyHIPE }\end{array}$ & $\begin{array}{l}\text { Retain the producer cells without any } \\
\text { clogging the matrix }\end{array}$ & (Jimat, 2011) \\
\hline $\begin{array}{l}\text { Flow-through monolithic } \\
\text { microbioreactors with immobilized } \\
\text { cells }\end{array}$ & $\begin{array}{l}\text { phenol-degrading bacteria, Pseudomonas } \\
\text { syringae,was immobilized in microbioreactor } \\
\text { in monolithic form }\end{array}$ & $\begin{array}{l}\text { The control of bioreaction can be carried } \\
\text { out at a microscopic level, } \\
\text { the reactor volume is drastically reduced, } \\
\text { therefore providing all the advantages of } \\
\text { classical process intensification technology }\end{array}$ & (Erhan et al., 2004) \\
\hline Enzymatic membrane reactor & Enzymatic hydrolysis of casein & $\begin{array}{l}\text { Residence time required is reduced and the } \\
\text { utilisation of substrate substantially increased }\end{array}$ & $\begin{array}{l}\text { (Trusek-Holownia, } \\
\text { 2008) }\end{array}$ \\
\hline Micro-cellular polyme & $\begin{array}{l}\text { Microcellular polyHIPE polymer supports } \\
\text { osteoblast growth and bone formation in vitro }\end{array}$ & $\begin{array}{l}\text { Significant increase in osteoblast numbers } \\
\text { penetrating into the polymer, } \\
\text { highly porous scaffold with a potential for } \\
\text { bone tissue engineering }\end{array}$ & (Akay et al., 2004) \\
\hline $\begin{array}{l}\text { Methods } \\
\text { enzymes immobilization }\end{array}$ & $\begin{array}{l}\text { Immobilization of glucose isomerase (on an } \\
\text { inorganic carrier) for production of high fructose } \\
\text { corn syrup, penicillin G acylase(covalently } \\
\text { attached to polyacrylate) for the production of } \\
\text { semi-synthetic penicillins, lactase(on an ion- } \\
\text { exchange resin) for producing low-lactose } \\
\text { milk, TL lipase (on silica) for fat modification }\end{array}$ & $\begin{array}{l}\text { Obtaining adequate productivity, } \\
\text { improvements in activity, stability and } \\
\text { selectivity }\end{array}$ & (Drauz, 2012) \\
\hline Cells immobilization & Beer fermentation using immobilised yeast cells & High-productivity & (Verbelen et al., 2010) \\
\hline Rotating bed of porous packings & $\begin{array}{l}\text { Using a rotating bed of porous packings for } \\
\text { application to an } E \text {. coli batch fermentation process }\end{array}$ & $\begin{array}{l}\text { Intensification of gas-liquid mass transfer } \\
\text { Higher overall } E \text {. coli cell growth rate }\end{array}$ & (Boodhoo et al., 2008) \\
\hline Membrane based processes & Lactic acid production & $\begin{array}{l}\text { Continuous removal of lactic acid from } \\
\text { fermentation broth } \\
\text { Fermentation is carried out in a continuous mode } \\
\text { Higher productivity }\end{array}$ & (Pal et al., 2009) \\
\hline Reactive crystallization & $\begin{array}{l}\text { Efficient calcium lactate production by } \\
\text { Fermentation coupled with crystallization-based } \\
\text { in-situ product removal }\end{array}$ & Higher average productivity & (Xu and $\mathrm{Xu}, 2014$ ) \\
\hline Membrane absorption & $\begin{array}{l}\text { Recovery and purification of biofuel compounds, } \\
\text { including ethanol, iso-propanol, n-propanol, } \\
\text { iso-butanol, n-butanol, } 2 \text { methyl-1-butanol, } \\
\text { 3-methyl-1-butanol and n-pentanol }\end{array}$ & Economic recovery & (Nielsen et al., 2010) \\
\hline Liquid-liquid extraction & $\begin{array}{l}\text { In-situ product removal of phenol from P. Putida } \\
\text { S12TPL fermentations } \\
\text { Recovery of fermentative carboxylic acids }\end{array}$ & Increased yields and productivity & $\begin{array}{l}\text { (Heerema et al., 2011; } \\
\text { López-Garzón and } \\
\text { Straathof, 2014) }\end{array}$ \\
\hline Ultrasound & $\begin{array}{l}\text { Shikonin production in L. Erythrorhizon } \\
\text { cell cultures }\end{array}$ & $\begin{array}{l}\text { Enhance shikonin production in cell cultures, } \\
\text { increased extraction yield from } 20 \text { to } 65-70 \% \text {, } \\
\text { due partially to an increase in the cell } \\
\text { membrane permeability by sonication }\end{array}$ & (Cai et al., 2012) \\
\hline
\end{tabular}




\begin{tabular}{|c|c|c|c|}
\hline Membrane absorption & $\begin{array}{l}\text { In-situ Product Recovery of n-Butanol } \\
\text { In-situ product removal of phenol from } \\
\text { P. Putida S12TPL fermentations }\end{array}$ & $\begin{array}{l}\text { Enhancing the yield of n-butanol and } \\
\text { economical purification } \\
\text { Increased yields and productivity }\end{array}$ & $\begin{array}{l}\text { (Nielsen and Prather, } \\
\text { 2009; Heerema et al., } \\
\text { 2011) }\end{array}$ \\
\hline Electrodialysis & $\begin{array}{l}\text { Recovery of pyruvic acid from fermentation broth } \\
\text { Recovery of fermentative carboxylic acids }\end{array}$ & $\begin{array}{l}\text { Separate pyruvate without using solvents, } \\
\text { to concentrate the product and to } \\
\text { minimize process waste-water }\end{array}$ & $\begin{array}{l}\text { (Zelić and Vasić-Rački, } \\
\text { 2003) }\end{array}$ \\
\hline Membrane extraction & $\begin{array}{l}\text { Removal of inhibiting products from a } \\
\text { fermentation broth }\end{array}$ & Reduce the fouling and improve the filtrate flux & (Heerema, 2012) \\
\hline Anion exchanger-based & $\begin{array}{l}\text { Microbial production of propionic acid with } \\
\text { Propionibacterium freudenreichii }\end{array}$ & $\begin{array}{l}\text { Increased productivity and product yield, with a } \\
\text { corresponding decrease in the number of } \\
\text { downstream processing steps, as well as in } \\
\text { substrate consumption }\end{array}$ & (Wang et al., 2012) \\
\hline Adsorption & $\begin{array}{l}\text { Fumaric acid recovery from fermentation broth } \\
\text { Recovery of fermentative carboxylic acids }\end{array}$ & Increased the yield and productivity & $\begin{array}{l}\text { (Xu et al., 2012; } \\
\text { López-Garzón and } \\
\text { Straathof, 2014) }\end{array}$ \\
\hline Adsorption-desorption & $\begin{array}{l}\text { In-situ recovery of } 3 \text {-hydroxypropionaldehyde } \\
\text { (3HPA) during biotransformation of glycerol by } \\
\text { Lactobacillus reuteri }\end{array}$ & 2 times higher productivity of $3 \mathrm{HPA}$ & (Sardari et al., 2014) \\
\hline Dynamic fermentation & $\begin{array}{l}\text { Simultaneous biosynthesis and recovery of } \\
\text { menaquinone- } 7\end{array}$ & $\begin{array}{l}\text { Enhanced yield of fermentation process, with a } \\
\text { corresponding decrease in the number of } \\
\text { downstream processing steps }\end{array}$ & (Berenjian et al., 2014) \\
\hline
\end{tabular}

Table 4. Potential energy savings due to investment in PI in a range of process unit operations

\begin{tabular}{lc}
\hline Process & Energy saving (PJ/a) \\
\hline Compact heat exchangers & 16.0 \\
Separators & 6.2 \\
Reactors & 11.0 \\
Overall plant intensification & 40.0 (technical potential) \\
Effluent treatment & 1.0 \\
\hline
\end{tabular}

\section{Future of BPI}

Several authors have emphasized that PI has, or will have, a major role to play in the future of chemical and biochemical engineering. The phrase 'molecules into money' was used in proposing that chemical process engineering drives today's economic development and wealth creation, the process engineering being, of course, based on PI. Despite the compelling benefits of PI for the process industry it has to be admitted that there have been and still are, serious obstacles which have been responsible for its relatively slow adoption since its inception around two decades ago. In the context of an existing fully established and depreciated plant, it is extremely difficult to introduce unproven intensified equipment. The conservatism of plant owners using batch processes means will not easily accept continuous processing solutions. A mature technology in the process industry is usually associated with the existence of design codes and packages. A developing technology such as PI is not yet embodied in such design codes. The provision of this information is an important next step for the relevant equipment vendors. PI modules should be incorporated into relevant university courses and students must be encouraged to question conventional thinking and be given the chance to experiment with intensified equipment. Another important factor involves the lack of demonstration facilities in which clients' processes may be performed on intensified equipment. A successful outcome to such trials is a very powerful motivator for the adoption of the new technology.

\section{Conclusion}

Challenges in the industry such as competitive products for the same indication or desired cost reductions are forcing many researchers to explore new production options. Process intensifying equipment such as novel reactors and process intensifying methods such as new separations are expected to bring significant improvements in energy saving, safety, company profitability, equipment size, production capacity and waste production of the processes. However, there are also limitations to PI and an awareness of these is essential if correct application is to be ensured for the future of sustainable process engineering.

\section{Author's Contributions}

All authors contributed extensively to the work presented in this paper.

\section{References}

Akay, G., 2005. Bioprocess and chemical process intensification. Encyclopedia Chem. Process. DOI: $10.1081 /$ E-ECHP-120022532

Akay, G., M. Birch and M. Bokhari, 2004. Microcellular polyHIPE polymer supports osteoblast growth and bone formation in vitro. Biomaterials, 25: 39914000. DOI: 10.1016/j.biomaterials.2003.10.086

Akay, G., E. Erhan and B. Keskinler, 2005. Bioprocess intensification in flow-through monolithic microbioreactors with immobilized bacteria. Biotechnol. Bioeng., 90: 180-190. DOI: $10.1002 /$ bit.20376

Al Taweel, A., F. Azizi and G. Sirijeerachai, 2013. Static mixers: Effective means for intensifying mass transfer limited reactions. Chem. Eng. Process., 72: 51-62. DOI: 10.1016/j.cep.2013.08.009 
Anxionnaz, Z., M. Cabassud, C. Gourdon and P. Tochon, 2008. Heat Exchanger/Reactors (HEX reactors): Concepts, technologies: State-of-the-art. Chem. Eng. Process., 47: 2029-2050.

DOI: $10.1016 /$ j.cep.2008.06.012

Berenjian, A., R. Mahanama, A. Talbot, H. Regtop and J. Kavanagh et al., 2014. Designing of an intensification process for biosynthesis and recovery of menaquinone-7. Applied Biochem. Biotechnol., 172: 1347-1357. PMID: 24173914

Boodhoo, K., M. Vicevic, C. Cartwright, T. Ndlovu and E. Toogood, 2008. Intensification of gas-liquid mass transfer using a rotating bed of porous packings for application to an $E$. coli batch fermentation process. Chem. Eng. J., 135: 141-150. DOI: $10.1016 /$ j.cej.2007. 06.011

Boodhoo, K.V., C.D. Cartwright, M. Vicevic, M.A. Prieto and M. Tortajada, 2010. Development of a Higee Bioreactor (HBR) for production of polyhydroxyalkanoate: Hydrodynamics, gas-liquid mass transfer and fermentation studies. Chem. Eng. Process., 49: 748-758.

DOI: $10.1016 /$ j.cep.2010.01.005

Cai, Z., A. Kastell, D. Knorr and I. Smetanska, 2012. Exudation: An expanding technique for continuous production and release of secondary metabolites from plant cell suspension and hairy root cultures. Plant Cell Reports, 31: 461-477. PMID: 21987121

Charpentier, J.C., 2007. In the frame of globalization and sustainability, process intensification, a path to the future of chemical and process engineering (molecules into money). Chem. Eng. J., 134: 84-92. DOI: $10.1016 /$ j.cej.2007.03.084

Cheng, H.H. and C.S. Tan, 2009. Carbon dioxide capture by blended alkanolamines in rotating packed bed. Energy Proc., 1: 925-932. DOI: $10.1016 /$ j.egypro.2009.01.123

DECC, 2012. Department of Energy and Climate Change.

Drauz, K., 2012. Enzyme Catalysis in Organic Synthesis: A Comprehensive Handbook. 1st Edn., John Wiley and Sons.

Dunford, N.T., 2012. Food and Industrial Bioproducts and Bioprocessing. 1st Edn., John Wiley and Sons, Ames, ISBN-10: 0813821053, pp: 392.

Erhan, E., E. Yer, G. Akay, B. Keskinler and D. Keskinler, 2004. Phenol degradation in a fixed-bed bioreactor using micro-cellular polymer-immobilized Pseudomonas syringae. J. Chem. Technol. Biotechnol., 79: 195-206. DOI: 10.1002/jctb.938

Feng, X., D.A. Patterson, M. Balaban, G. Fauconnier and E.A.C. Emanuelsson, 2013. The spinning cloth disc reactor for immobilized enzymes: A new process intensification technology for enzymatic reactions. Chem. Eng. J., 221: 407-417.

DOI: $10.1016 /$ j.cej.2013.02.020
Clark, J.H., F. EI Deswarte and T.J. Farmer, 2009. The integration of green chemistry into future biorefineries. Biofuels, Bioproducts Biorefin., 3: 72-90. DOI: $10.1002 / \mathrm{bbb} .119$

Heerema, L., N. Wierckx, M. Roelands, J.H. Hanemaaijer and E. Goetheer et al., 2011. In situ phenol removal from fed-batch fermentations of solvent tolerant Pseudomonas putida $\mathrm{S} 12$ by pertraction. Biochem. Eng. J., 53: 245-252. DOI: $10.1016 /$ j.bej. 2010.11.002

Heerema, L.D., 2012. In-situ product removal by membrane extraction. PhD Thesis, Delft University of Technology.

Hendershot, D.C., 2003. Process Intensification for Safety. In: Re-Engineering the Chemical Processing Plant: Process Intensification andrzej Stankiewicz, Jacob A. Moulijn (Eds.), CRC Press, ISBN-10: 0203913299, pp: 471-535.

Jimat, D.N., 2011. Bioprocess intensification: Production of a-amylase by immobilised Bacillus subtilis in porous polymeric polyHIPE. PhD Thesis. University of Newcastle upon Tyne.

López-Garzón, C.S. and A.J.J. Straathof, 2014. Recovery of carboxylic acids produced by fermentation. Biotechnol. Adv., 32: 873-904. DOI: 10.1016/j.biotechadv.2014.04.002

Lutze, P., R. Gani and J.M. Woodley, 2010. Process intensification: A perspective on process synthesis. Chem. Eng. Process., 49: 547-558. DOI: $10.1016 /$ j.cep.2010.05.002

Marques, M.P. and P. Fernandes, 2011. Microfluidic devices: Useful tools for bioprocess intensification. Molecules, 16: 8368-8401. DOI: $10.3390 /$ molecules 16108368

Ni, X., J. Cosgrove, R. Cumming, C. Greated and K. Murray et al., 2001. Experimental study of flocculation of bentonite and Alcaligenes eutrophus in a batch oscillatory baffled flocculator. Chem. Eng. Res. Design, 79: 33-40.

DOI: $10.1205 / 026387601528507$

Nielsen, D.R., G.S. Amarasiriwardena and K.L. Prather, 2010. Predicting the adsorption of second generation biofuels by polymeric resins with applications for In Situ Product Recovery (ISPR). Bioresource Technol., 101: 2762-2769. PMID: 20044248

Nielsen, D.R. and K.J. Prather, 2009. In situ product recovery of n-butanol using polymeric resins. Biotechnol. Bioeng., 102: 811-821. PMID: 18831001

Nikoleris, D., R. Arias and M. O'Conner, 2002. Delphi study on process intensification technologies. M.Sc. Thesis, Heriot-Watt University, Edinburgh.

Pal, P., J. Sikder, S. Roy and L. Giorno, 2009. Process intensification in lactic acid production: A review of membrane based processes. Chem. Eng. Process., 48: 1549-1559. DOI: 10.1016/j.cep.2009.09.003 
Reay, D., C. Ramshaw and A. Harvey, 2013. Process Intensification: Engineering for Efficiency, Sustainability and Flexibility. 2nd Edn., Butterworth-Heinemann, Oxford, ISBN-13: 0080983057, pp: 624.

Reis, N., C. Gonçalves, A. Vicente and J. Teixeira, 2006. Proof-of-concept of a novel micro-bioreactor for fast development of industrial bioprocesses. Biotechnol. Bioeng., 95: 744-753. DOI: 10.1002/bit.21035

Sardari, R.R., T. Dishisha, S.H. Pyo and R. Hatti-Kaul, 2014. Semicarbazide-functionalized resin as a new scavenger for in situ recovery of 3hydroxypropionaldehyde during biotransformation of glycerol by Lactobacillus reuteri. J. Biotechnol., 192: 223-230. PMID: 25456063

Stankiewicz, A.I. and J.A. Moulijn, 2000. Process intensification: Transforming chemical engineering. Chem. Eng. Progress, 96: 22-34.

Stringaro, J.P., P. Collins and O. Bailer, 1998. Open Cross-Flow-Channel Catalysts and Catalyst Supports. In: Structured Catalysts and Reactors, Cybulski, A. (Ed.), CRC Press, ISBN-10: 0824799216, pp: 393-416.

Trusek-Holownia, A., 2008. Production of protein hydrolysates in an enzymatic membrane reactor. Biochem. Eng. J., 39: 221-229. DOI: $10.1016 /$ j.bej.2007.09.010

Van Hecke, W., G. Kaur and H. De Wever, 2014. Advances in In-Situ Product Recovery (ISPR) in whole cell biotechnology during the last decade. Biotechnol. Adv., 32: 1245-1255. DOI: 10.1016/j.biotechadv.2014.07.003

Verbelen, P.J., V.A. Nedović, V. Manojlović, F.R. Delvaux and I. Laskošek-Čukalović et al., 2010. Bioprocess Intensification of Beer Fermentation Using Immobilised Cells. In: Encapsulation Technologies for Active Food Ingredients and Food Processing, Zuidam, N.J. and V. Nedovic (Eds.), Springer, New York, ISBN-10: 1441910085, pp: 303-325.
Wang, M., A. Lawal, P. Stephenson, J. Sidders and C. Ramshaw, 2011. Post-combustion $\mathrm{CO}_{2}$ capture with chemical absorption: A state-of-the-art review. Chem. Eng. Res. Design, 89: 1609-1624. DOI: $10.1016 /$ j.cherd.2010.11.005

Wang, P., Y. Wang and Z. Su, 2012. Microbial production of propionic acid with Propionibacterium freudenreichii using an anion exchanger-based In Situ Product Recovery (ISPR) process with direct and indirect contact of cells. Applied Biochem. Biotechnol., 166: 974-986.

DOI: $10.1007 / \mathrm{s} 12010-011-9485-7$

Wohlgemuth, R., 2009. The locks and keys to industrial biotechnology. New Biotechnol., 25: 204-213. DOI: $10.1016 /$ j.nbt.2009.01.002

$\mathrm{Xu}, \mathrm{K}$. and $\mathrm{P}$. $\mathrm{Xu}, 2014$. Efficient calcium lactate production by fermentation coupled with crystallization-based in situ product removal. Bioresource Technol., 163: 33-39. DOI: 10.1016/j.biortech.2014.04.002

$\mathrm{Xu}$, Q., S. Li, H. Huang and J. Wen, 2012. Key technologies for the industrial production of fumaric acid by fermentation. Biotechnol. Adv., 30: 16851696. PMID: 22940403

Yi, F., H.K. Zou, G.W. Chu, L. Shao and J.F. Chen, 2009. Modeling and experimental studies on absorption of $\mathrm{CO}_{2}$ by Benfield solution in rotating packed bed. Chem. Eng. J., 145: 377-384. DOI: 10.1016/j.cej.2008.08.004

Zelić, B. and Đ. Vasić-Rački, 2003. Recovery of pyruvic acid from fermentation broth: Process development and modeling. University of Zagreb. 